\title{
THE PROTECTIVE ACTION OF ANAESTHETICS AGAINST HYPOXIA
}

\author{
O. SECHER, M.D., D.M.S., AND B. WILHJELM, M.D. ${ }^{*}$
}

UNTIL RECENTLY interest in examining the protective action of anaesthetics on brain cells exposed to hypoxia has been sporadic (for references see Wilhjelm ${ }^{1}$ ). In recent years different groups of investigators in Canada, ${ }^{2} \mathrm{USA}^{3,4}$ India, ${ }^{5}$ and Denmark ${ }^{1,6-8}$ have shown interest in this problem. For many years it has been recognized that barbiturates were able to reduce the cerebral oxygen uptake both clinically and in vitro, and we know that patients who survive barbiturate poisoning rarely have cerebral damage even after a long period of unconsciousness.

We became interested in this subject as a result of reviewing our anaesthetic technique for obstetrical cases, especially the acute cases where the infant was often in a state of hypoxia at delivery. It is generally considered that if the newborn baby is to begin respiration immediately after birth it must be free from the effects of any anaesthetics given to the mother. It is also generally accepted that slowing of the heart rate in the foetus indicates hypoxia and the correct treatment of this state is immediate delivery. A barbiturate induction immediately before delivery is generally considered to be contraindicated, due to the danger of depression of the respiratory centre in the child.

We came to the conclusion that this technique might be wrong and possibly harmful, if we could prove that anaesthetics and particularly barbiturates, which we know influence brain metabolism, have a protective action which increases the organism's resistance to anoxia. If this theory is right we should aim at anaesthetizing the baby before delivery, particularly in cases of foetal distress. The anaesthetic which it is possible to introduce most rapidly is a barbiturate.

With these thoughts in mind we began experiments on mice. We chose mice in order to obtain valuable information and because by using these small animals it was possible to use an adequate number of controls in each experiment. On the other hand the experiments were carried out without any special form for recording our results. The main criterion of the effects of anoxia-with and without the addition of anaesthetics-was the death of the animal; the only measurement made was of survival time. Survival time may be defined as the period between the commencement of anoxia and the death of the animal as registered by the last breath. We thought that the lack of more detailed information could be counterbalanced by the large number of animals used in each experiment.

The technique used was simple and reproducible and has been repeated in all the experiments. The equipment used in the beginning is shown in a schematic form in Figure 1. The animals were placed in jars in a thermostable box with a

'Dr. Secher is Professor of Anaesthesia, University of Copenhagen, Denmark, and Chief Anaesthetist, Rigshospitalet (University Hospital), Copenhagen. Dr. Wilhjelm is Research Fellow, Anaesthesia Laboratory, Pharmacological Institute, University of Copenhagen. 


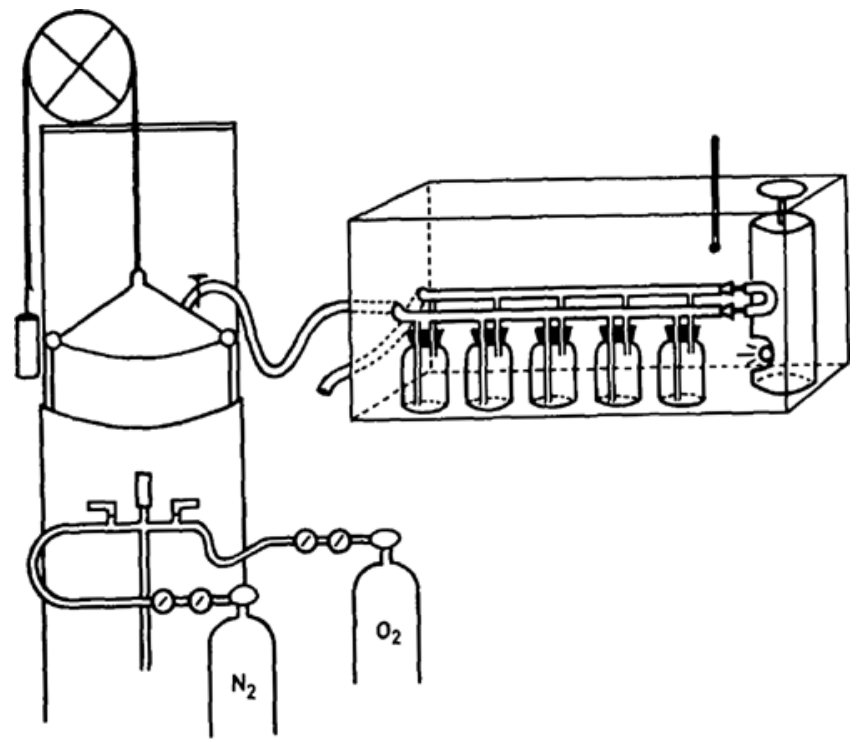

Figure 1. Experimental apparatus. To the left is a spirometer, to the right a thermostat with glass containers for the experimental animals.

temperature of $24^{\circ} \mathrm{C}$., and a mixture of nitrogen and oxygen was blown through the jars. ${ }^{6}$ The experiments took place therefore under standard conditions and with standard animals.

Thiopentone was the first drug tested on the mice; this was injected intravenously in the tail. The animals were placed together with an equal number of controls in the different chambers.

From these experiments we were able to make a rather rough curve of the tolerance of the animals to anoxia (Fig. 2). From this curve it may be clearly seen that when the oxygen concentration reaches 4 per cent something of utmost importance occurs. It looks as if the "anoxia, which not only stops the motor, but also wrecks the machinery" (Barcroft), occurs when the oxygen concentration falls to 4 per cent. When the oxygen is above 5 per cent the survival time increases very rapidly. Reliable results were difficult to obtain when the oxygen concentration was over 5 per cent, and anoxia lasting more than five minutes gave rise to a wide spreading of the results. When the animals were treated with thiopentone the curve was pushed roughly 1 per cent to the left.

These experiments were very stimulating, and we decided to improve the technique and test a wide range of anaesthetic drugs.

The experimental set-up was altered so that both volatile and gaseous agents could be tested (Fig. 3). The standard conditions were maintained and the animals were the same, but the temperature in the chambers was increased from $24^{\circ}$ to $32^{\circ}-34^{\circ}$, as it was thought that the low temperature might have had some influence on the spreading of the results. When the gaseous and volatile agents were used, the animals were anaesthetized for ten minutes before the onset of anoxia in order to obtain stable conditions. The survival time in all experiments 

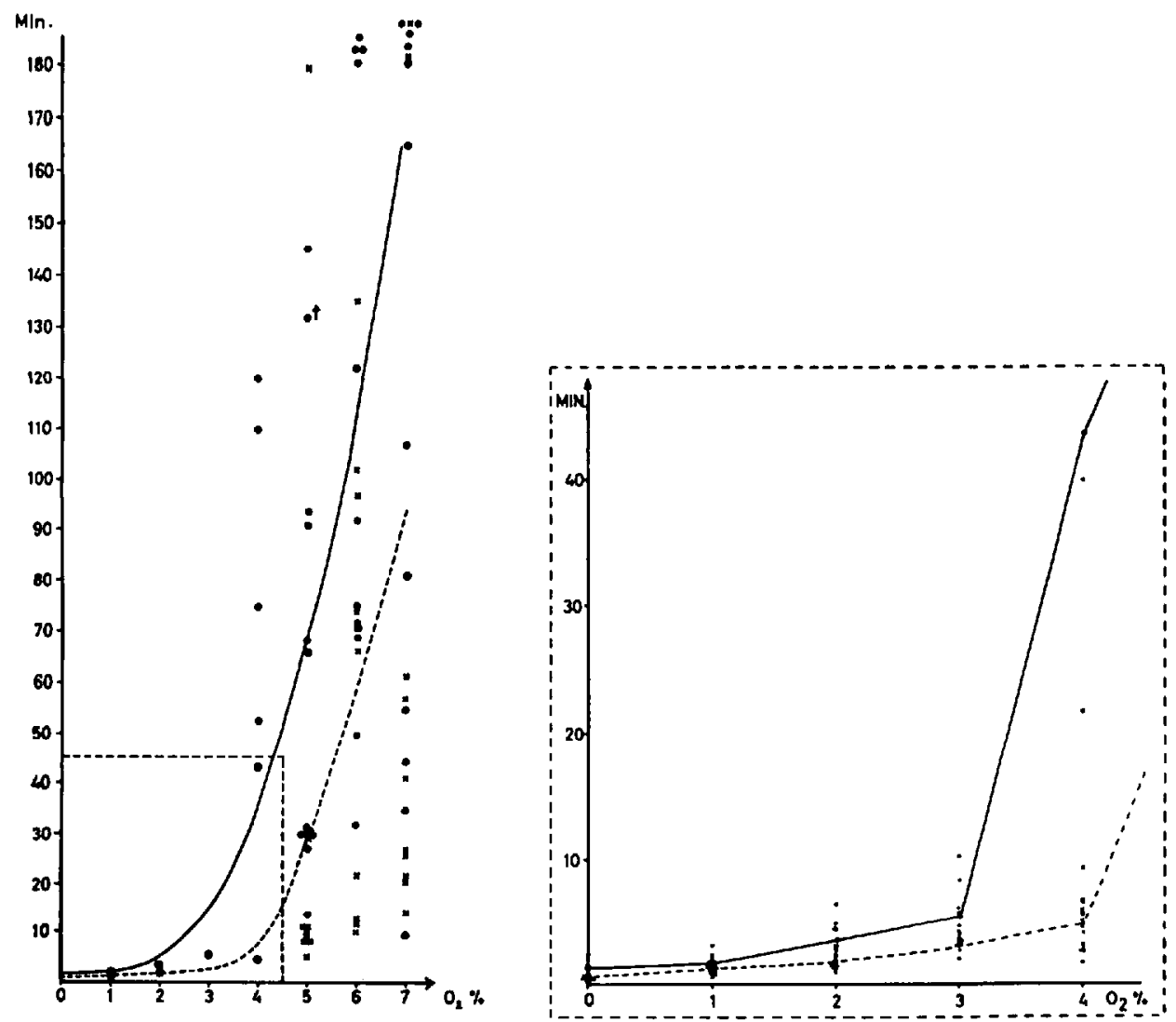

FIgUre 2. Graphical statement of survival times for mice anaesthetized with barbiturates and for control animals. The abscissa indicates the oxygen percentage in the gas mixture, the ordinate indicates time in minutes. Curves are recorded by probable average values. For the anaesthetized mice the curve is completely recorded; the average lifetime of the control animals is indicated by a dotted curve. The field with the lowest oxygen percentages, where the curves are placed very close to each other, is repeated on the right of the figure on a larger scale.

was measured with an oxygen concentration of 5 per cent in 95 per cent nitrogen.

Figures 4 and 5 show the results of the influence of the different drugs. One hundred mice were used for each experiment; 50 received the drug to be tested, and 50 were used as controls. ${ }^{7,8}$

The first evidence revealed that the drug with the greatest effect was undoubtedly thiopentone. Halothane, and cyclopropane were the next most effective drugs among those first tested. Ether and methoxyflurane had very little effect. All the intravenous anaesthetics were effective, but none could be compared with thiopentone. The action of thiopentone and halothane combined was only moderate, although these two drugs individually gave the greatest increase in survival time. All the experiments, including those with other drugs, are summarized in Table $I$, which shows the percentage increase in survival time. ${ }^{7,8}$

On examining the results it was suspected that the anaesthetized animals had a high carbon dioxide retention compared to the control animals: such a retention 
TABLE I

Average Survival Time (in Minutes) of Non-anaesthetized Control Mice and Anaesthetized Mice, and Percentage Prolongation of the Survival Time*

\begin{tabular}{lccc}
\hline \hline \multicolumn{1}{c}{ Anaesthetic } & $\begin{array}{c}\text { Control mice } \\
\text { (min.) }\end{array}$ & $\begin{array}{c}\text { Anaesthetized } \\
\text { mice (min.) }\end{array}$ & $\begin{array}{c}\text { Prolongation } \\
\text { of survival } \\
\text { time (\%) }\end{array}$ \\
\hline Thiopentone & 3.13 & 7.95 & 154.0 \\
Ether & 3.06 & 3.06 & 0.0 \\
Chloroform & 3.57 & 3.98 & 11.5 \\
Trichlorethylene & 2.65 & 2.87 & 8.3 \\
Cyclopropane & 2.86 & 4.12 & 44.1 \\
Halothane & 2.69 & 4.96 & 84.4 \\
Methoxyflurane & 2.94 & 3.30 & 12.2 \\
Nitrous oxide & 2.78 & 2.52 & 9.4 \\
Urethane & 2.59 & 4.62 & 78.5 \\
Hydroxydione & 2.44 & 4.55 & 86.4 \\
Detrovel & 2.54 & 3.79 & 49.3 \\
Thiopentone and halothane & 2.98 & 4.67 & 56.7 \\
\hline
\end{tabular}

*In calculating the average survival times the highest values have been excluded.

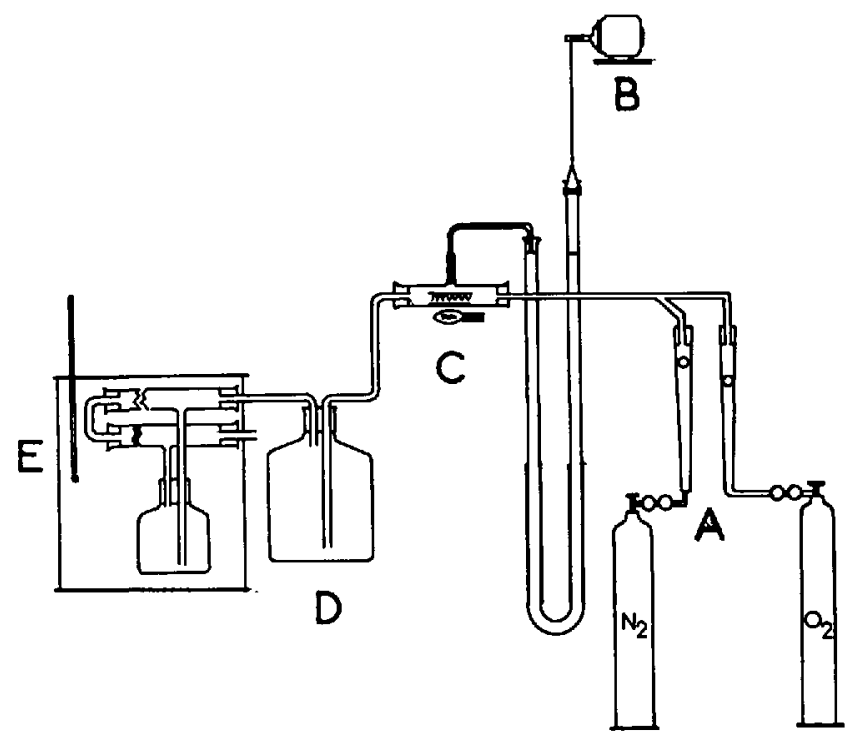

FIGURE 3. Experimental mounting of anaesthesia apparatus. A-Steel cylinders containing nitrogen and oxygen. B-Electromotor. C-Evaporation chamber. D-Mixing chamber. EThermostat with bottles for experimental animals.

of carbon dioxide would increase the cerebral circulation and prolong the survival time. The fact that death occurred earlier in the control animals than in the anaesthetized animals could be due to the convulsions which occurred much earlier in the control animals. Convulsions in the anaesthetized animals did not occur until very late.

On the other hand, all the anaesthetized animals died in convulsions, although these convulsions were less severe than those seen in the control animals. The difference in the magnitude of the convulsions could explain the moderate 


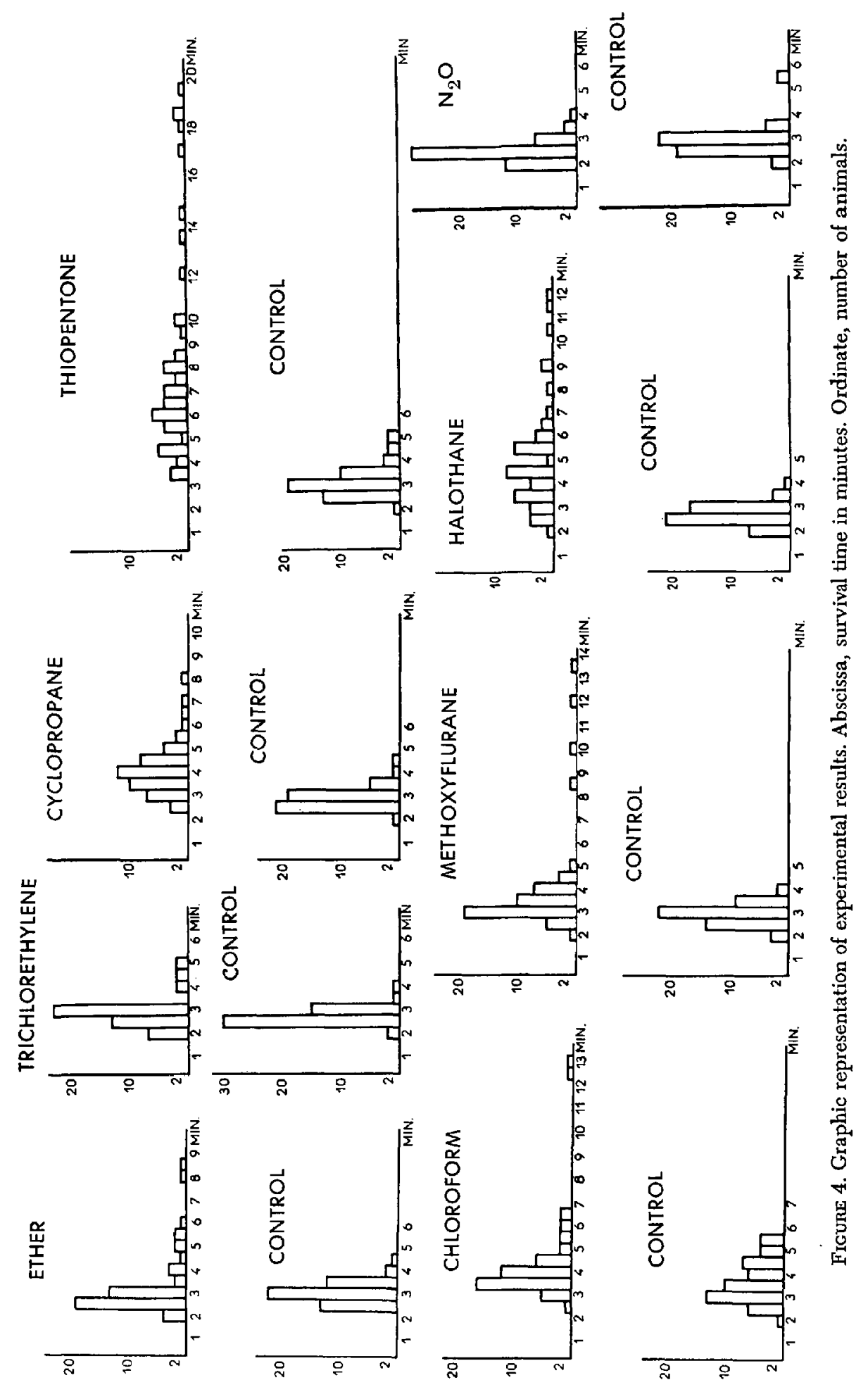



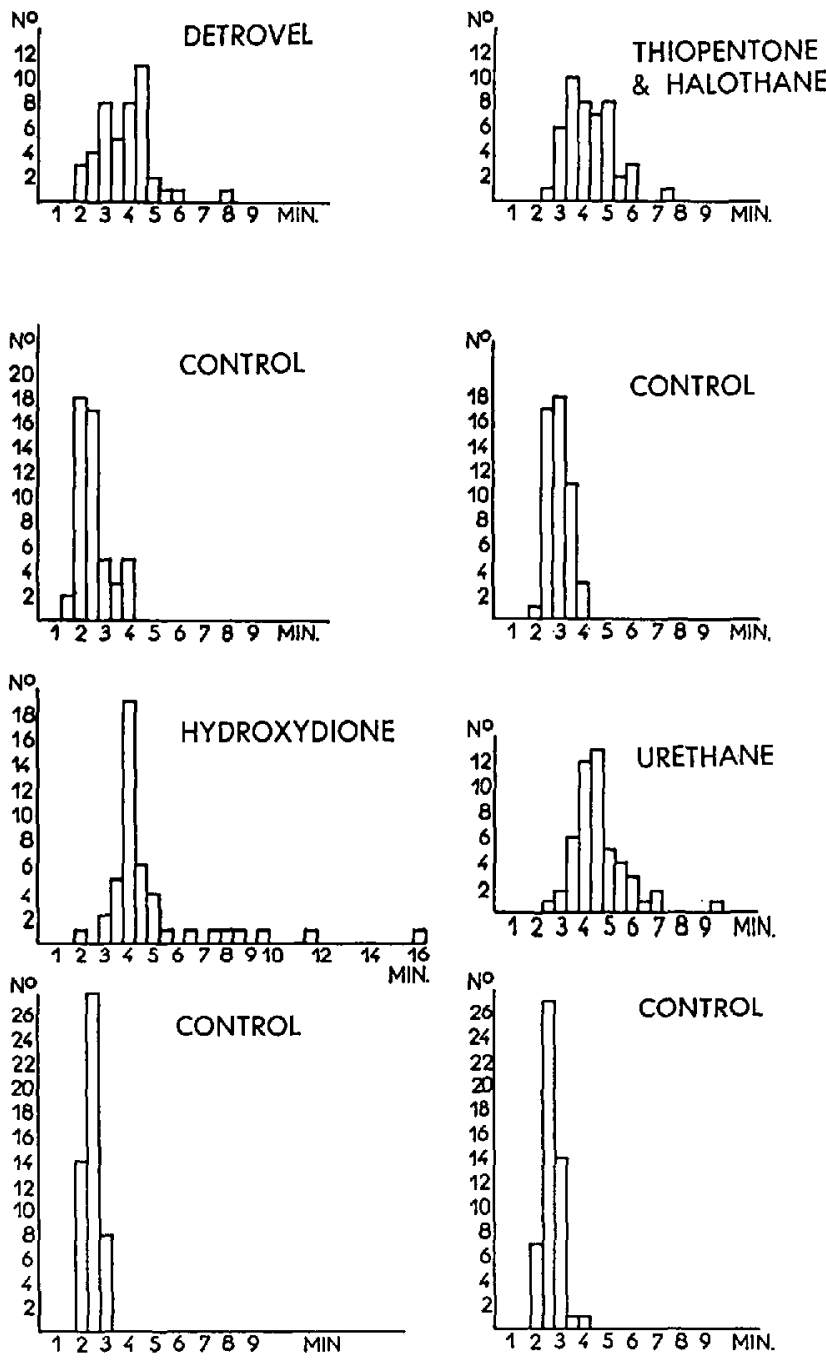

Figure 5. Graphic representation of experimental results. Abscissa, survival time in minutes. Ordinate, number of animals.

increase in survival time seen with drugs such as ether and methoxylurane, but not the very marked increase in survival time seen with thiopentone, halothane, and cyclopropane.

Drugs like hydroxydione and Detrovel increase the respiratory rate, and animals anaesthetized with these drugs cannot have a high carbon dioxide tension. Therefore, the increased survival time with these drugs cannot be due to retention of carbon dioxide.

In an attempt to throw light upon the problem of carbon dioxide retention we compared the influence of carbon dioxide in concentrations ranging from 2.5 per cent up to 20 per cent. These animals were compared with others receiving the same low concentration of oxygen. In these experiments 25 animals were used in each group. ${ }^{11}$ 
We found that a concentration of 5 per cent carbon dioxide increased the survival time 137 per cent, the same magnitude as for thiopentone. Concentrations above and below 5 per cent had a significantly smaller influence on the survival time.

When thiopentone and 5 per cent carbon dioxide were tested together there was a marked increase in the animals' survival time to $300-400$ per cent as compared to the controls. Halothane combined with carbon dioxide gave no further increase in survival time. These experiments are shown in Figures 6 and 7 and are summarized in Table II. Here the influence of convulsions can be excluded, as all animals under the influence of carbon dioxide died in convulsions.

These experiments suggest the following conclusions.
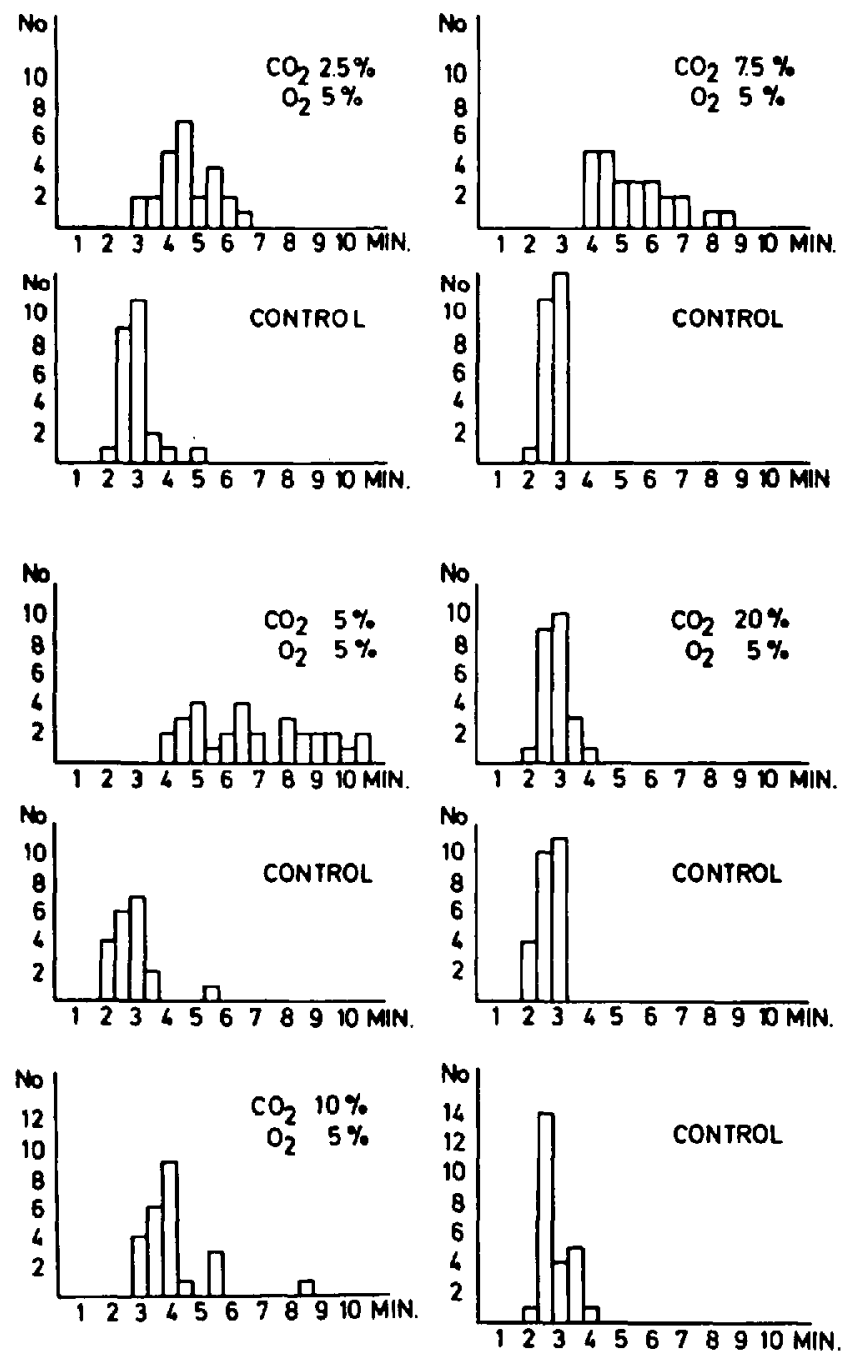

Figure 6. Graphic representation of experimental results. Abscissa, survival time in minutes. Ordinate, number of animals. 

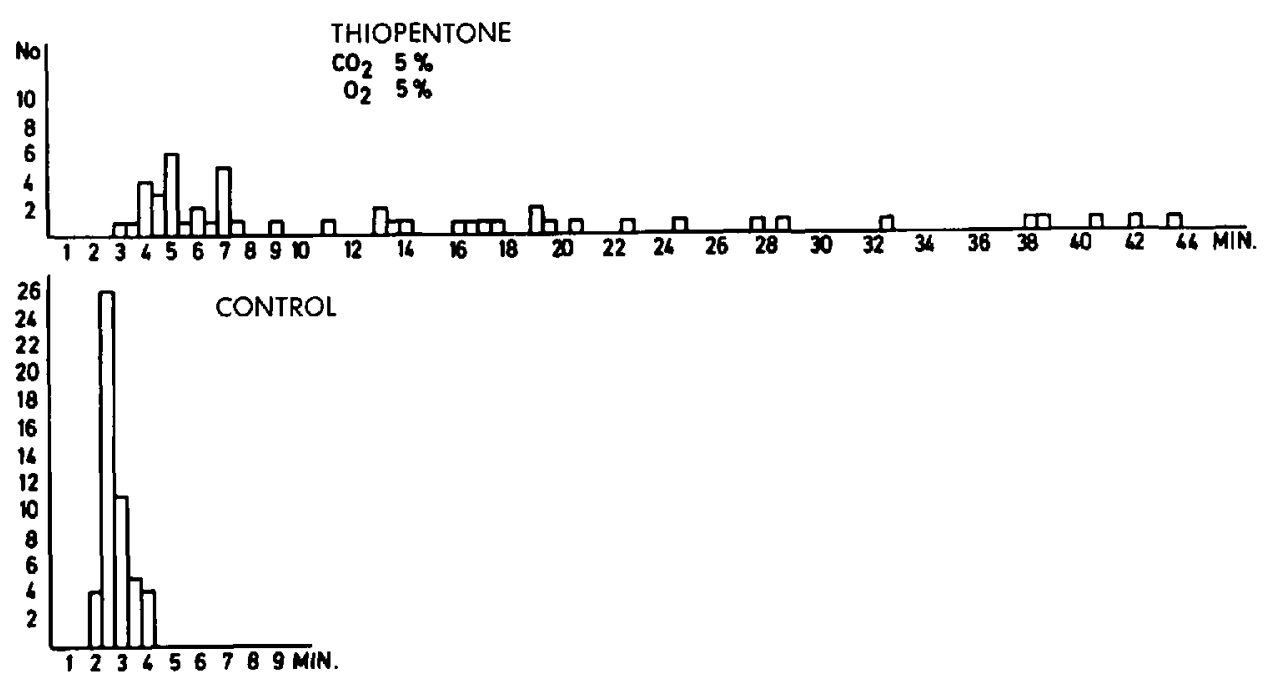

Frgure 7. Graphic representation of experimental results. Abscissa, survival time in minutes. Ordinate, number of animals.

\section{TABLE II}

Influence of Carbon Dioxide and of Anaesthesta and Carbon Dioxide on SuRvival Trme*

\begin{tabular}{|c|c|c|c|c|c|}
\hline \multicolumn{2}{|c|}{$\begin{array}{l}\text { Anoxic. untreated } \\
\text { control animals }\end{array}$} & \multicolumn{3}{|c|}{$\begin{array}{l}\text { Anoxic experimental animals exposed to } \\
\text { inspiration of carbon dioxide }\end{array}$} & \multirow[b]{2}{*}{$\begin{array}{l}\text { Prolongation } \\
\text { of survival } \\
\text { time (\%) }\end{array}$} \\
\hline $\begin{array}{l}\text { survival } \\
\text { period } \\
\text { (min.) }\end{array}$ & s.e.m. & $\begin{array}{c}\text { carbon dioxide } \\
\text { concentration } \\
(\%)\end{array}$ & $\begin{array}{l}\text { survival } \\
\text { period } \\
\text { (min.) }\end{array}$ & s.e.m. & \\
\hline $\begin{array}{l}2.9 \\
2.9 \\
2.7 \\
2.8 \\
2.6\end{array}$ & $\begin{array}{l}0.14 \\
0.18 \\
0.06 \\
0.10 \\
0.03\end{array}$ & $\begin{array}{r}2.5 \\
5.0 \\
7.5 \\
10.0 \\
20.0\end{array}$ & $\begin{array}{l}4.4 \\
6.9 \\
5.4 \\
4.1 \\
2.9\end{array}$ & $\begin{array}{l}0.32 \\
0.21 \\
0.26 \\
0.24 \\
0.08\end{array}$ & $\begin{array}{r}50 \\
137 \\
98 \\
45 \\
12\end{array}$ \\
\hline \multicolumn{2}{|c|}{$\begin{array}{l}\text { Anoxic, untreated } \\
\text { control animals }\end{array}$} & \multicolumn{3}{|c|}{ Anaesthetized, anoxic experimental animals } & \multirow[b]{2}{*}{$\begin{array}{c}\text { Prolongation } \\
\text { of survival } \\
\text { time }(\%)\end{array}$} \\
\hline $\begin{array}{c}\text { survival } \\
\text { period } \\
\text { (min.) }\end{array}$ & s.e.m. & anaesthetic & $\begin{array}{c}\text { survival } \\
\text { period } \\
\text { (min.) }\end{array}$ & s.e.m. & \\
\hline 2.8 & 0.10 & \multirow{3}{*}{$\begin{array}{l}\text { Thiopentone and } \\
\text { carbon dioxide } \\
\text { Halothane and } \\
\text { carbon dioxide } \\
\text { Thiopentone } \\
\text { Halothane }\end{array}$} & \multirow{2}{*}{14.1} & \multirow{2}{*}{1.67} & \multirow{2}{*}{400} \\
\hline 2.9 & 0.07 & & & & \\
\hline $\begin{array}{l}3.1 \\
2.7\end{array}$ & 二 & & $\begin{array}{l}5.6 \\
8.0 \\
5.0\end{array}$ & $\frac{0.35}{-}$ & $\begin{array}{r}91 \\
154 \\
84\end{array}$ \\
\hline
\end{tabular}

*Fifty mice were used for each $\mathrm{CO}_{2}$ concentration, of which 25 served as controls. The oxygen concentration was 5 vol. \% in all the experiments. 
1. The influence of carbon dioxide increases the survival time as a result of an increase in the cerebral circulation.

The effect of carbon dioxide upon the cerebral circulation is known from other experiments, which have shown that a $\mathrm{PCO}_{2}$ of up to 60 can regulate the cerebral circulation. Above this value the cerebral blood flow is regulated by the blood pressure alone. ${ }^{\theta}$

2. The increase in survival time seen with thiopentone must be an action per se on the brain itself and is not a result of carbon dioxide retention.

3. There is a true additive effect of the combination of carbon dioxide and thiopentone.

4. Halothane, which is the inhalation anaesthetic drug with the most marked action on survival time, acts as dilator of the brain vessels. Addition of carbon dioxide does not prolong the survival time. Possibly halothane also acts upon the brain cells. This vasodilatory action upon the cerebral vessels has been confirmed by other investigators. ${ }^{10}$

5. The moderate prolongation of survival time occurring with the other anaesthetic drugs is probably due to the action of these drugs upon brain metabolism.

More recently we have tested other barbiturates and have found nembutal to have an action similar to thiopentone, with an even greater percentage increase in survival time (188\%). Allyl-propyl-barbiturate has a somewhat lesser effect (106.2\%). Amobarbital has an even smaller effect (56\%), and the animals do not go to sleep. Chlorpromazine, which has been claimed to have an action on the brain metabolism, proved completely ineffective in our experiments.

From these experiments it was now quite clear that some of the drugs examined, particularly thiopentone and halothane, must have some protective action on the brain. If these findings could be confirmed by other methods, eliminating the convulsive factor, the results would be more convincing. The following experiments, carried out by B. Wilhjelm and B. G. Lucas in London, have not been published before.

The experimental animals were guinea pigs with an average weight of $500 \mathrm{gm}$. In each experiment two animals were anaesthetized with thiopentone intraperitoneally and two were used as controls. All the animals received 100 per cent nitrogen for a period of $5 \frac{1}{2}$ minutes and were then resuscitated using cardiac massage and ventilation with pure oxygen. The interval between the start of resuscitation and the establishment of adequate ventilation and cardiac action was recorded for each animal. Thirty-two animals were used in the first experiment; sixteen of them acted as controls. The average resuscitation time for the anaesthetized animals was 8-9 minutes and for the controls 14.2 minutes; two of the anaesthetized and three of the control animals died.

The experiment was repeated on the surviving animals three hours later. No extra thiopentone was given. By this time all traces of the first dose of thiopentone should have disappeared. There was now practically no difference in the resuscitation times for the two groups. These investigations confirmed the results of the experiments on mice.

Following these experiments it was decided to investigate the effect of thiopentone on cardiac action. The ECG was registered continuously in animals 


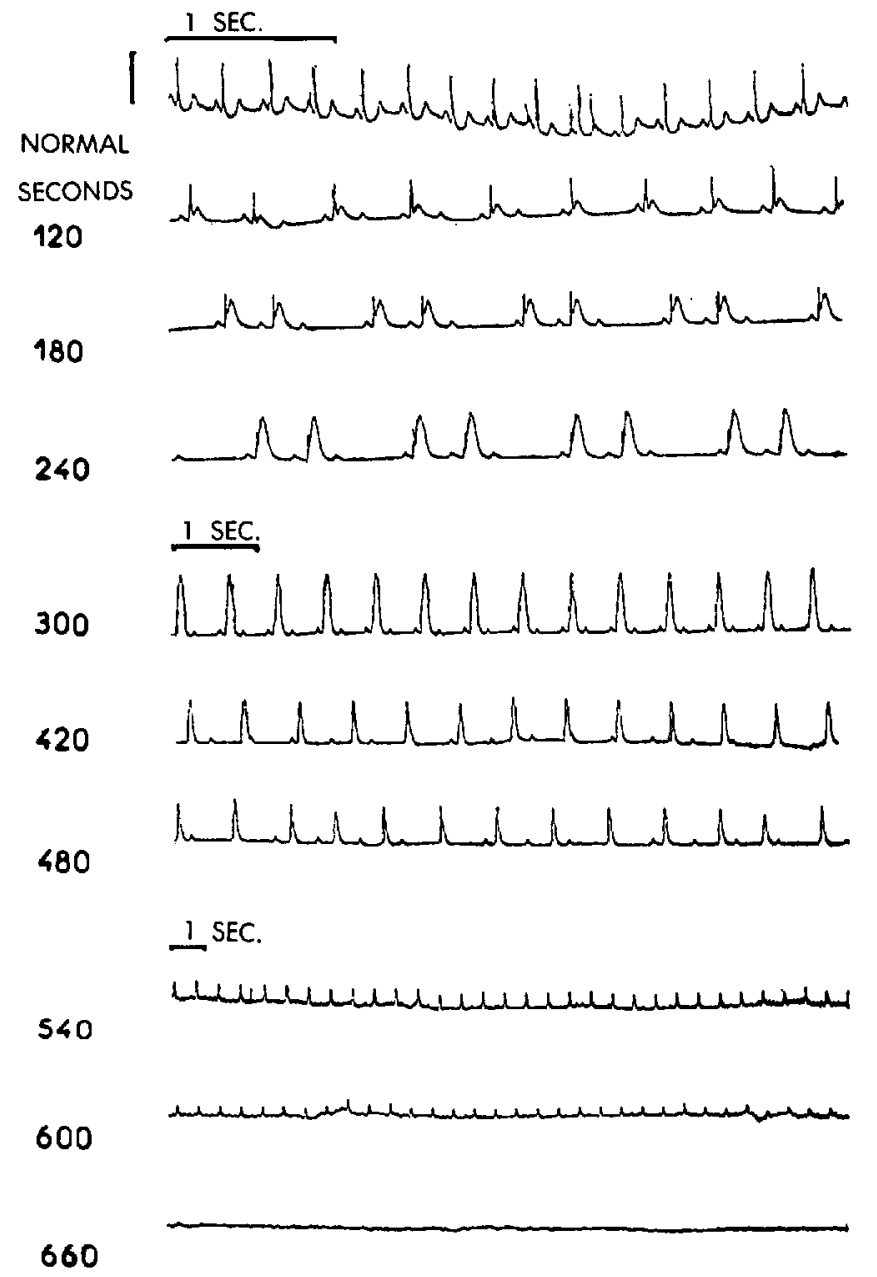

Figure 8. ECG readings with progressive anoxia.

before and after the administration of barbiturates, and the experiments were repeated on animals which were curarized and ventilated with 100 per cent nitrogen. Precordial leads were attached through steel sutures in the left side of the chest.

The ECG changes were similar in all groups of animals. They are shown in Figure 8 . The initial tachycardia is followed by bradycardia. The S-T interval is shortened and terminally the $T$ wave is seen to ascend from the $R$ wave. At the same time A-V dissociation and Wenchebachske periods appear. After 5-6 minutes only a single peak is seen and after 15-20 minutes the ECG becomes isoelectric. Twelve animals were used in each of the two experiments. These investigations show clearly that there is no difference between anaesthetized and control animals, and that the time elapsing before the ECG becomes isoelectric is the same in both groups.

Thiopentone does not increase cardiac resistance to the effects of anoxia. The changes seen on the ECG are similar to those found in patients suffering from a 
SECHER \& WILHJELM: ACTION OF ANAESTHETICS AGAINST HYPOXIA
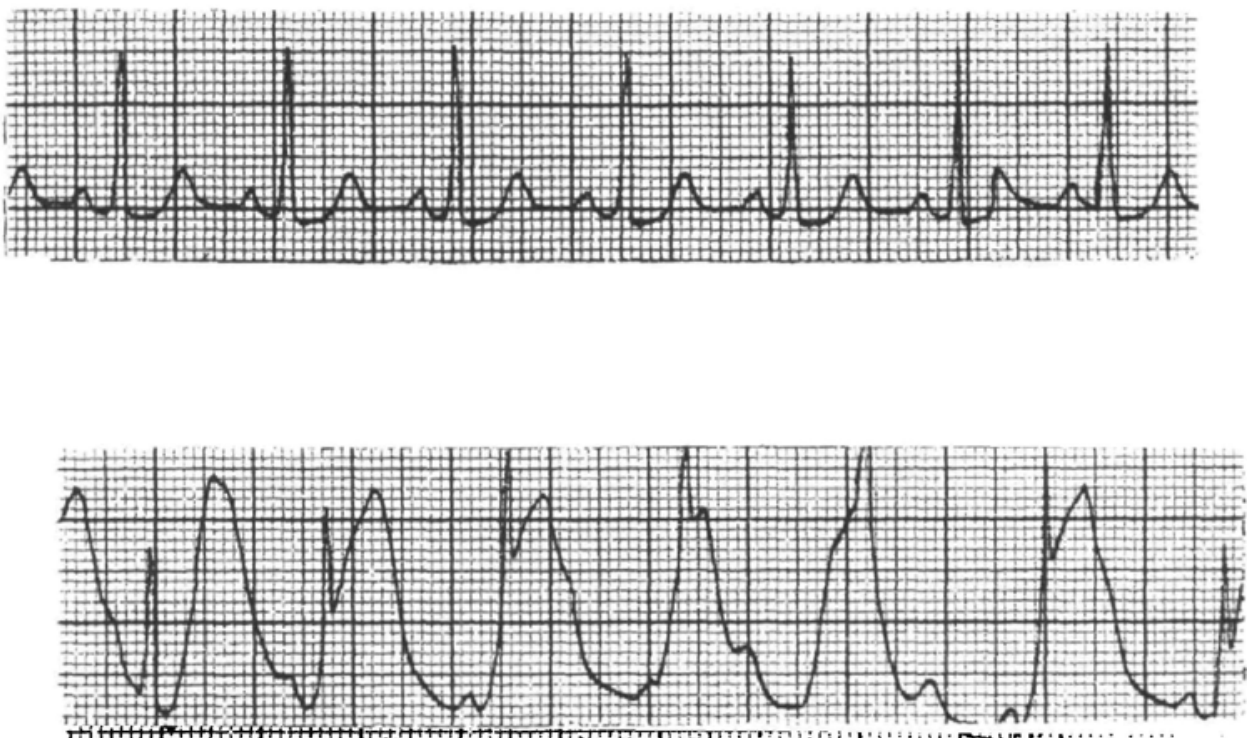

FIGURE 9. ECG tracing in human patients at compression of carotid arteries.

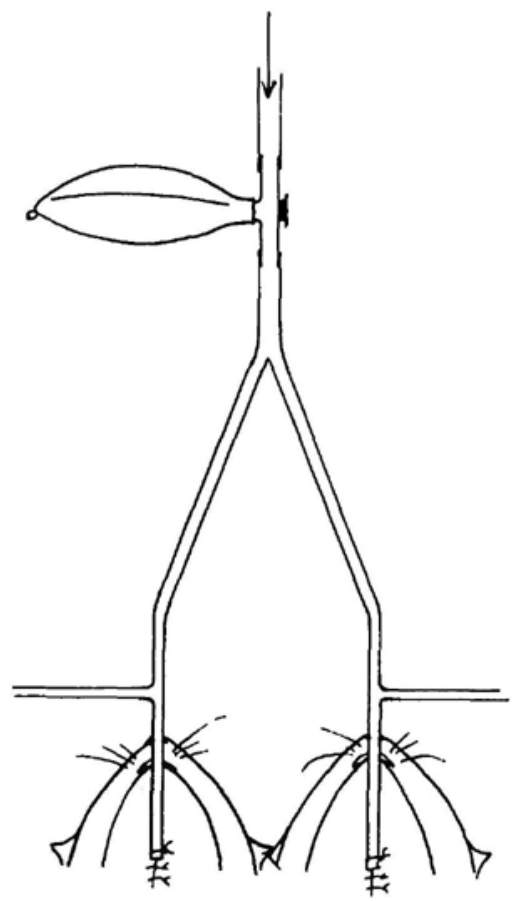

Figure 10. Experimental arrangement for ventilating guinea pigs. 

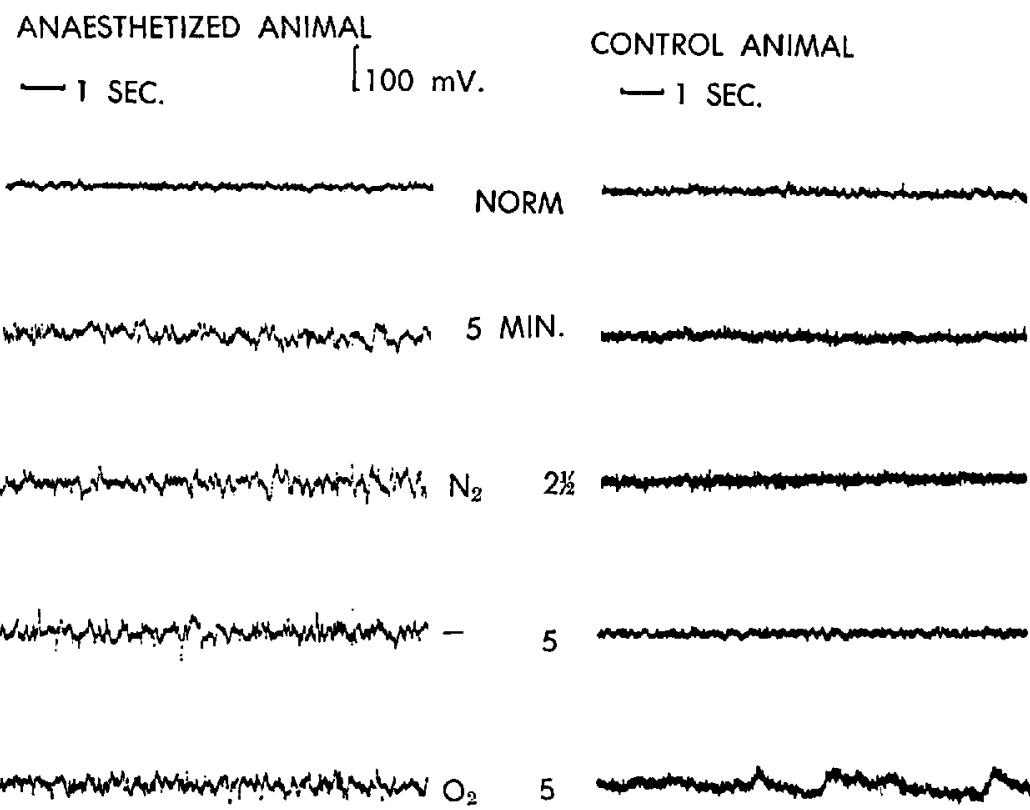

FIGURE 11. EEG readings with progressive anoxia.

compression of the carotid arteries (Fig. 9), as has also been demonstrated by Bain et al. ${ }^{2}$ in rabbits. These changes must be due to cerebral anoxia and not to myocardial ischemia.

By using larger animals it is possible to evaluate the changes occurring in the EEG, which can give valuable information relating to the influence of drugs on the brain function. If thiopentone protects the brain against anoxia it should be possible to register this effect on the EEG after the animal has been exposed to the effects of anoxia.

Guinea pigs were again used as the experimental animals. They were first tracheostomized, then curarized and ventilated under light ether anaesthesia. Half the animals were given thiopentone and the others were used as controls. The animals were ventilated in pairs so that an animal which had received 


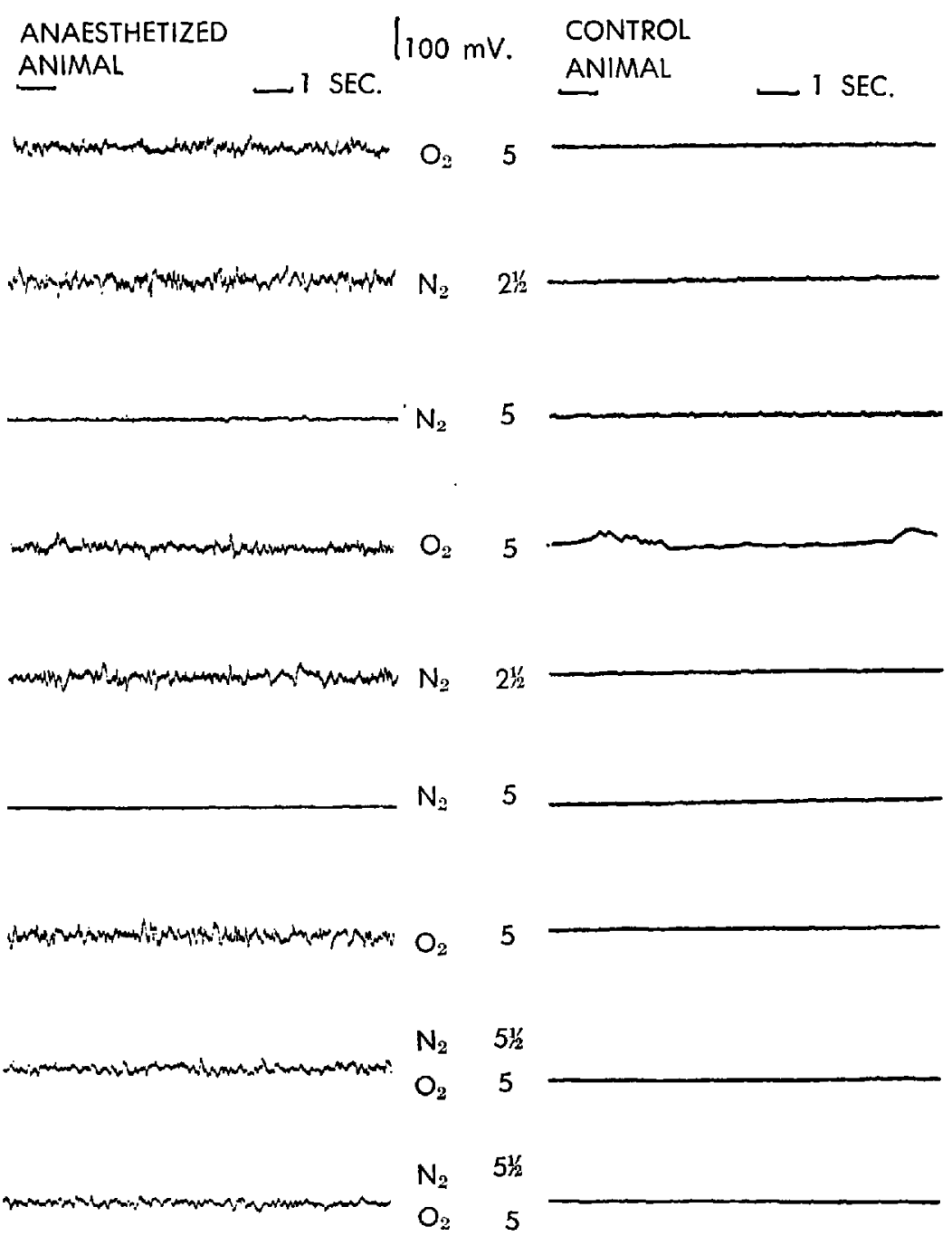

FIGURE 12. EEG readings with progressive anoxia.

barbiturate was ventilated together with a control animal (Fig. 10). Six anaesthetized and six control animals were used in this series.

During the experiments the EEG was recorded continuously. A state of anoxia was produced by ventilating the animal for $5 \%$ minutes with 100 per cent nitrogen, followed by five minutes' ventilation with pure oxygen. This process was repeated up to six times. Figures 11 and 12 show one of the experiments; all the other experiments were similar.

The normal EEG frequency, which is seen on the figure is 8-7 Hz., with an amplitude of $70 \mu \mathrm{V}$. The intraperitonal injection of thiopentone $(50-55 \mathrm{mg} . / \mathrm{kg}$.) results in the typical EEG pattern for sleep equivalent to that seen in man. From the EEG in Figures 11 and 12 it may be seen that cortical activity continues for a much longer period in the anaesthetized animal compared with the control 
animal. Furthermore, the EEG in the anaesthetized animal can return to normal even after several periods of anoxia and despite considerable changes in pattern and an isoelectric interval. The EEG in the control animal changes after four to five minutes. The frequency becomes slow and the amplitude smaller. Sometimes sharp waves are seen. During the first period of ventilation with oxygen the EEG returns to normal. The second period of anoxia is followed by EEG changes after three minutes, and after four minutes there is only a straight line. Following the third period of anoxia a normal EEG cannot be obtained.

The EEG in the control animals showed small peaks indicating the ECG, and that the animals were still alive. A state of isoelectricity is reached much later in the anaesthetized animals than in the controls. These investigations confirm the results of our experiments in mice and support the statement that barbiturates protect the brain against the effects of anoxia.

Let us then return to our starting point-anaesthesia for obstetrical cases. We have tried to make a control study on cases of caesarean section, but one of our greatest problems is the difficulty of obtaining a sufficient number of cases. We have for years attempted to register reliable information from all our caesarean sections and have evaluated the condition of the babies at birth by means of the Apgar score. The first 800 patients were anaesthetized with nitrous oxide and gallamine alone. We consider that in this group the effect of the anaesthetic on the baby should be negligible and this material has been used as a control against variations in the type of anaesthetic used for caesarean sections.

A series of patients were anaesthetized using a barbiturate for induction (enibomal $250 \mathrm{mg}$.), followed by nitrous oxide and gallamine. After 261 patients had been anaesthetized with this technique a comparison was made with 261 patients from the control series. Among the patients induced with barbiturate were 217 acute cases where there had not been time to prepare the patient for

TABLE III

Indications for Caesarean Section

\begin{tabular}{|c|c|c|c|c|}
\hline & \multicolumn{2}{|c|}{$\begin{array}{c}\text { Acute Caesarean } \\
\text { section }\end{array}$} & \multicolumn{2}{|c|}{$\begin{array}{l}\text { Non-acute Caesarean } \\
\text { section }\end{array}$} \\
\hline & enibomalum & control & enibomalum & control \\
\hline Contracted pelvis, etc. & 23 & 35 & 3 & 14 \\
\hline Mechanical disproportion & 29 & 24 & 8 & 3 \\
\hline Threatened uterine rupture & 2 & 4 & 0 & 0 \\
\hline Delay in labour & 35 & 34 & 2 & 0 \\
\hline Transverse presentation & 9 & 18 & 0 & 2 \\
\hline Breech presentation & 19 & 10 & 2 & 9 \\
\hline Unfavorable obstetrical history & 10 & 3 & $\overline{1}$ & 2 \\
\hline Placenta praevia & 19 & 16 & 3 & 2 \\
\hline Abruptio placentae & 10 & 13 & 0 & 0 \\
\hline Prolapse of the cord & 9 & 5 & 0 & 0 \\
\hline Foetal distress & 20 & 27 & 0 & 0 \\
\hline Rhesus immunisation & 1 & 8 & 11 & 5 \\
\hline Toxaemia of pregnancy & $\overline{7}$ & 10 & 2 & 2 \\
\hline Placental insufficiency & 9 & 3 & 6 & 1 \\
\hline Morbidity of the mother & 4 & 0 & 2 & 2 \\
\hline Miscellaneous & 11 & 7 & 4 & $\overline{2}$ \\
\hline Total & 217 & 217 & 44 & 44 \\
\hline
\end{tabular}


TABLE IV

BIRTH Weight OF Living INFANTS

\begin{tabular}{cccccc}
\hline & \multicolumn{2}{c}{ Acute Caesarean section } & & \multicolumn{2}{c}{ Non-acute Caesarean section } \\
Birth weight $(\mathrm{gm})$. & enibomalum & control & & enibomalum & control \\
\hline & $1(\mathrm{~d})$ & 0 & & 0 & 0 \\
$>1000$ & $2(2 \mathrm{~d})$ & $4(3 \mathrm{~d})$ & & 0 & 0 \\
$>1500-\leqq 2500$ & $34(6 \mathrm{~d})$ & $23(5 \mathrm{~d})$ & & $4(2 \mathrm{~d})$ & $2(\mathrm{~d})$ \\
$>2500-\leqq 3500$ & $104(\mathrm{~d})$ & $116(4 \mathrm{~d})$ & & $24(\mathrm{~d})$ & $24(\mathrm{~d})$ \\
$>3500-\leqq 4000$ & 49 & 45 & & $10(\mathrm{~d})$ & $11(\mathrm{~d})$ \\
& 26 & 26 & & 6 & 6 \\
Total & 216 & 214 & & 44 & 43 \\
\hline
\end{tabular}

$\mathrm{d}=$ Died within the first week. In the three lowest birth-weight categories, the weight at death was still under $2500 \mathrm{gm}$.

operation. For comparison we took 217 consecutive cases from the control series. The elective caesarean sections in these series amounted only to 44 cases; these were compared with 44 controls but the numbers were so small that no conclusions could be drawn. ${ }^{12}$

The two series of acute cases were comparable in respect to age and indications. Indications for caesarean section can be seen in Table III.

A comparison of the birth weights of the babies as seen in Table IV shows a larger number of babies with a low birth weight in the barbiturate series-41 as compared to 29 in the control series. The death rate was also lower in the barbiturate group; 10 babies died following delivery compared with 12 in the control group.

Table V shows the distribution of the Apgar scores. The average score for the babies in the barbiturate group is lower than for those in the control group, but the death rate was lower.

Mortality is highest in both groups among those cases where there is normally a high risk for the baby as with placenta praevia and abruptio placentae. By a coincidence the same number of caesarean sections were performed in both groups on these indications. However, the mortality in the barbiturate group was only half the mortality of the control group in these two types of cases, although the treatment of the babies after delivery was identical: aspiration of the stomach and artificial ventilation.

This study indicates that the use of barbiturates for induction in caesarean sections does not jeopardize the prognosis for the baby, but may make the baby sleepy, as is shown by the lower average Apgar score in the barbiturate group compared to the control group.

Owing to the average low birth weight in the barbiturate group it might be expected that the perinatal mortality would be high. However, this was not the case; on the contrary there was a higher survival rate than in the control group.

Our material is not large and it is therefore difficult to draw conclusions. If one can accept the idea that barbiturates have a beneficial influence on brain cells exposed to anoxia, this study can indicate that this theory applies also in clinical practice. 


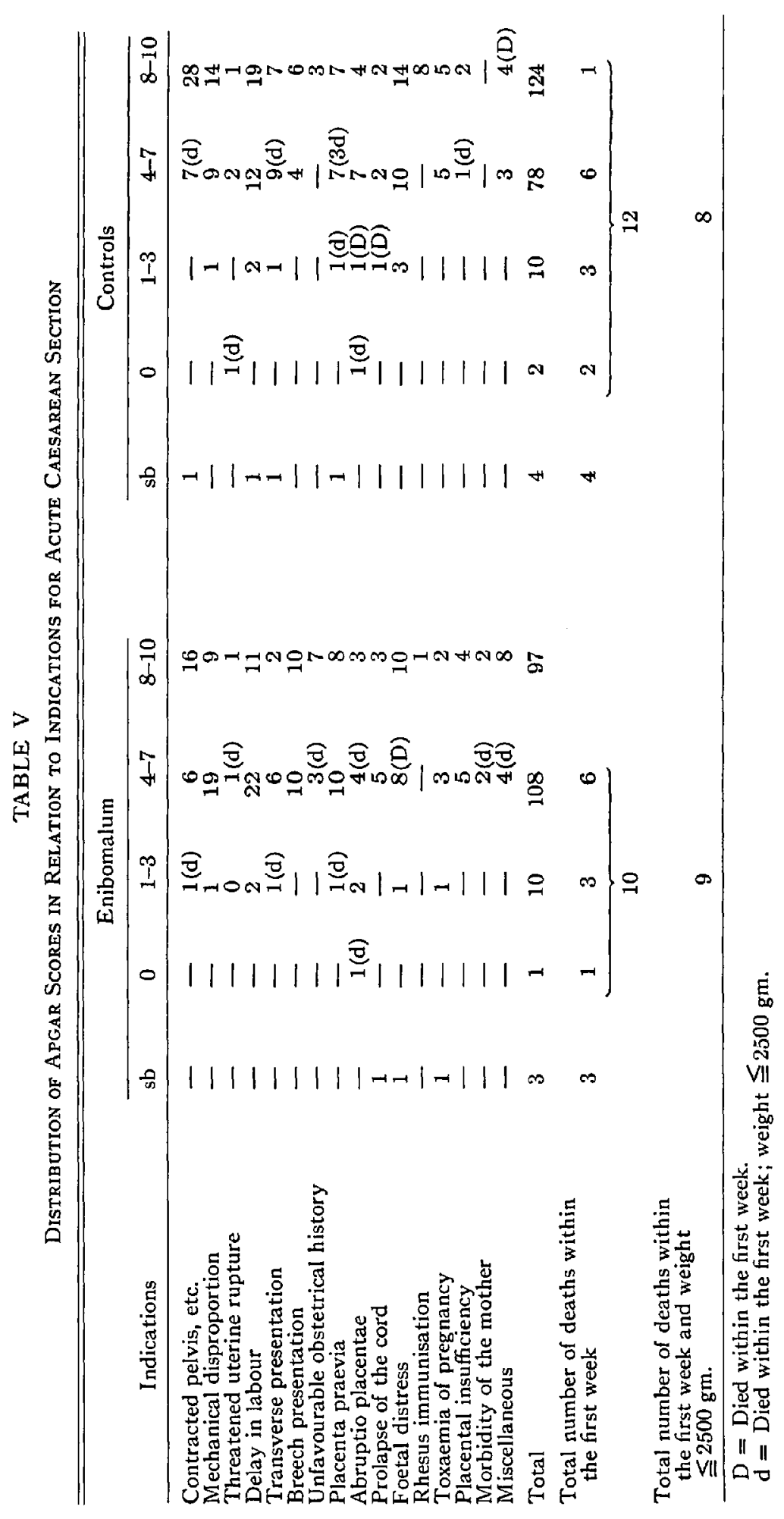


If our theory is right and our evaluation of the protective action of the different anaesthetic drugs is correct, then our technique of administering anaesthesia to patients expected to be exposed to the effects of anoxia should undergo a radical change. These patients at risk would include those undergoing brain surgery, cardiac surgery, and operations on the carotid artery. The technique should also be applied to cases of foetal distress and following cardiac arrest.

The patients should be given large doses of barbiturates intravenously, halothane, and possibly 5 per cent carbon dioxide. Hyperventilation and alkalosis must be avoided. In obstetric cases the infants should be delivered under the influence of large doses of anaesthetic drugs, particularly barbiturates, in order to start life with the best chance-especially if there have been signs of foetal distress before delivery. After delivery we are able to obtain control of the situation by adequate treatment. If our findings are correct it should be possible for us to give a better start to a considerable number of future world citizens.

\section{SUMMARY}

On the basis of experimental examinations it has been possible to show that halothane and cyclopropane of the inhalation anaesthetics have a protective action on the brain against anoxia. A similar but even better effect could be obtained by most intravenous anaesthetics, particularly thiopentone. If thiopentone was combined with 5 per cent carbon dioxide, this effect was doubled.

In obstetrical anaesthesia in 217 caesarean sections a barbiturate was used for induction. This lowered the Apgar score of the children, but probably increased the survival rate.

The conclusion to be drawn from these experimental and clinical studies would be that patients who have a possibility of being exposed to anoxia or are under influence of anoxia should preferably be anaesthetized with intravenous barbiturate anaesthetics and in this way be protected to some degree against the damaging influence of anoxia.

\section{RÉSUMÉ}

Il nous a été possible de démontrer expérimentalement que l'halothane et le cyclopropane parmi les agents anesthésiques par inhalation exercaient un effet protecteur sur le cerveau contre l'hypoxie. Avec les agents anesthésiques par voie endoveineuse, particulièrement le thiopentone, il est possible d'obtenir une effet semblable et même supérieur. Si le thiopentone est associé à l'inhalation de 5 pour cent de $\mathrm{CO}_{2}$, l'effet obtenu est doublé.

En anesthésie obstétricale, au cours de 217 césariennes, nous avons employé un barbiturique pour faire l'induction. Cette façon de faire a modifié l'évaluation d'Apgar pour les enfants en l'abaissant, mais fort probablement a augmenté le taux de survie.

Les conclusions à tirer de ces expériences et de ces études cliniques sont les suivantes: les malades qui seraient exposés à subir une hypoxie ou qui sont déjà sous l'effet d'une hypoxie devraient être anesthésiés de préférence par des barbituriques par voie endoveineuse; de cette façon, ils pourraient être assurés d'une certaine protection contre l'influence nuisible de l'hypoxie. 


\section{REFERENCES}

1. Wilhjelm, B. J. Effect of Thiomebumal upon resistance of Mice to Anoxia. International Anesthesiology Clinics (Boston: Little, Brown, 1966), vol. 4, no. 2, pp. 399-413.

2. Bain, J. A.; Catron, D. V.; Cox, J. M. R.; \& Spoerel, W. E. The Effect of General Anaesthesia on the Tolerance of Cerebral Ischaemia in Rabbits. Canad. Anaesth. Soc. J. 14: 69 (1967).

3. Goldstein, A.; Wells, B. A.; \& Keats, A. S. Increased Tolerance to Cerebral Anoxia by Pentobarbital. Arch. internat. pharmacodyn. 161: 138 (1966).

4. Wells, B. A.; Keats, A. S.; \& Cooley, D. A. Increased Tolerance to Cerebral Ischemia Produced by General Anesthesia during Temporary Carotid Occlusion. Surgery. 54: $216(1963)$.

5. Dhruva, A. J.; Javeri, P. M.; Parulkar, G. B.; Bhatt, M. M.; \& Sen, P. K. Fluothane as an Anaesthetic Adjuvant for Prevention of Hypoxic Brain Damage. Exper. Med. Se. 5: 1 (1961).

6. Annfred, I. \& Secher, O. Anoxia and Barbiturates: Tolerance to Anoxia in Mice Influenced by Barbiturates. Arch. internat. pharmacodyn. 139: 67 (1962).

7. Wilmolem, B. J. \& Arnfred, I. Protective Action of Some Anaesthetics against Anoxia. Acta pharmacol. et toxicol. 22: 93 (1965).

8. WIIнJеLM, B. J. Further Investigations into the Protective Action of Anaesthetics against Anoxia in Mice. Acta pharmacol. et toxicol. 22: 131 (1965).

9. Harper, A. M. The Inter-relationship between $\mathrm{PCO}_{2}$ and Blood Pressure in the Regulation of Blood Flow through the Cerebral Cortex. In D. H. Ingvar \& N. A. Lassen (ed.), Regional Cerebral Blood Flow. Symposium. Munksgaard. Copenhagen (1965), pp. 94-103.

10. Christensen, M. S.; Hфedt-Rasmussen, K.; \& Lassen, N. A. Cerebral Vasodilatation by Halothane Anaesthesia in Man and Its Potentiation by Hypotension and Hypercapnia. Brit. J. Anaesth. 39: 927 (1967).

11. Wilhjelm, B. J. Protective Action of Carbon Dioxide against Anoxia with and without Anaesthesia. Acta pharmacol. et toxicol. 24: 355 (1966).

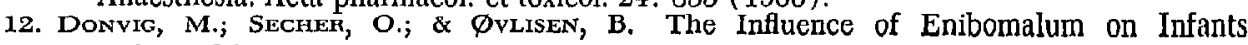
Delivered by Caesarean Section. Acta anaesth. scandinav. 11: 25 (1967). 